\title{
Estimation of Potential Lifetime Cancer Risks for Trihalomethanes from Consuming Chlorinated Drinking Water in Taiwan ${ }^{1}$
}

\author{
Ching-Hung Hsu, * Woei-Lih Jeng, $\dagger$ Ruey-Mai Chang, $\$$ Ling-Chu Chien, ${ }^{*}$ and Bor-Cheng Han ${ }^{* 2}$ \\ *School of Public Health, Taipei Medical University, 250 Wu-Hsing Street, Taipei, Taiwan, Republic of China \\ $\dagger$ Institute of Oceanograghy, National Taiwan University, Taipei, Taiwan, Republic of China; and $\$$ Institute of Nuclear Science, National \\ Tsing Hua University, Hsin-Chu, Taiwan, Republic of China
}

Received December 16, 1999; published online November 30, 2000

Data on concentrations of trihalomethanes (THMs) in raw and chlorinated water collected from three water treatment plants in Taiwan and estimates of the lifetime cancer risk for THMs from drinking water, using age-adjusted factors and volatilization terms, are presented. Data on THM levels in drinking water were obtained from the annual reports of the Environmental Protection Administration (EPA) of Taiwan. The methodology for estimation of lifetime cancer risks was taken from the USEPA. Chloroform was the major species of THMs, especially in the water plant of south Taiwan. Chloroform contributed the majority of the lifetime cancer risks (range: $87.5-92.5 \%$ ) of total risks from the three water supply areas. All lifetime cancer risks for $\mathrm{CHCl}_{3}, \mathrm{CHBrCl}_{2}, \mathrm{CHBr}_{2} \mathrm{Cl}$, and $\mathrm{CHBr}_{3}$ from consuming tap water in the three water supply areas were higher than $10^{-6}$. The sum of lifetime cancer risks for $\mathrm{CHCl}_{3}, \mathrm{CHBrCl}_{2}, \mathrm{CHBr}_{2} \mathrm{Cl}$, and $\mathrm{CHBr}_{3}$ was highest (total risk for total THMs $<1.94 \times 10^{-4}$ ) for tap water from south Taiwan. (c) 2000 Academic Press

Key Words: trihalomethanes; exposure; cancer risks; Taiwan; drinking water.

\section{INTRODUCTION}

Water is required to sustain life, but has long been a source of much human illness. In Taiwan, water sources are mostly $(59.3 \%)$ drawn directly from rivers; the rest comes from groundwater and reservoirs, accounting for 21.7 and $19.0 \%$, respectively.

\footnotetext{
${ }^{1}$ This study was supported by grants from the National Science Council, Republic of China (NSC-87-2815-C-038-014-B).

${ }^{2}$ To whom correspondence should be addressed. Fax: 886-22738-4831. E-mail: bchan@mail.tmc.edu.tw.
}

Surface water and groundwater sources have be come increasingly contaminated due to increased industrial and agricultural activity. Nearly half of the rivers in Taiwan (48\%) were found to be more or less polluted. In 1996, the water quality of most of the smaller tributaries, which are also tap water sources, was rather good (EPA, 1996).

Most of the potable water in Taiwan is tap water, supplying water to $84.2 \%$ of the population, or 17,312,204 persons. According to the Taiwan Water Works Corp., $77 \%$ of its tap water comes from surface water, $30 \%$ of which has been more or less polluted. It is known that when water sources are polluted, the costs of treatment (such as chlorine) will increase. When a water source is badly polluted, it can never be used for tap water. The Taiwan EPA reported that $30.01 \%$ and $4.81 \%$ of the tap water were unacceptable due to the excessive total bacteria and coliform bacteria contents, respectively (EPA, 1996).

Most sources of municipal water supplies are surface waters and are often treated with chlorine. The nonmunicipal sources are mainly privately owned wells (groundwater) and are often unchlorinated. Chlorination has been the major strategy for the disinfection of drinking water on Taiwan. It is currently added to approximately $75.8 \%$ of the nation's drinking water.

Chlorination of drinking water has been one of the most effective public health measures ever undertaken (Bull et al., 1995). In the 1970s it was found that chlorine reacted with natural organic matter present in surface water to produce disinfection byproducts (DBPs). Special concerns are associated with the trihalomethanes (THMs) because they have been recognized as potentially hazardous and are the major by-products of chlorination (Bull et al., 1995). Chloroform is found in municipal water 
supplies that are disinfected by chlorination, the most common disinfection process in Taiwan (Yang et al., 1998).

Epidemiological studies examining the health effects of chlorinated water have found that populations exposed to chlorination by-products have elevated rates of bladder (Cantor et al., 1998; McGeehin et al., 1993), colon-rectum (Hildesheim et al., 1998), and brain (Cantor et al., 1999; Wilikins et al., 1979; Lawrence et al., 1984; Flaten, 1992) cancers. Animal studies have demonstrated that liver, kidney, and intestinal tumorigeneses are associated with chronic ingestion of trihalomethanes (Dunnick and Melnick, 1993; Doyle et al., 1997). As summarized in a recent meta-analysis by Morris et al. (1992), higher exposure to chlorination byproducts in drinking water may be related to an approximately 10 to $40 \%$ excess risk of cancers of the bladder and colon-rectum. It has also been suggested that there is an association between exposure to chlorination by-products in water and adverse reproductive outcomes (Kramer et al., 1992; Bove et al., 1995). THMs in drinking water have been related to spontaneous abortion (Waller et al., 1998). In Taiwan, Yang et al. (1996) indicated that there was a significant association between municipal (chlorinated) drinking water in Taiwan and mortality from certain cancers. On the other hand, the results of that study suggest a positive association between consumption of chlorinated drinking water and cancer of the rectum, lung, bladder, and kidney because chlorination of water is so widely practiced in Taiwan.

Individuals are exposed to volatile compounds present in tap water by ingestion, inhalation, and dermal absorption. Traditional risk assessments for water often consider only ingestion exposure to toxic chemicals, even though showering has been shown to increase the body burden of certain chemicals due to inhalation exposure and dermal absorption. Accordingly, it has been proposed that inhalation and dermal absorption need to be considered in the analysis of total human exposure to volatile contaminants in tap water (Jo et al., 1990; Maxwell et al., 1991; Weisel and Jo, 1996; Weisel et al., 1999; Lin and Hoang, 2000).

This study presents the concentrations of THMs in raw and chlorinated water collected from three different water treatment plants in Taiwan. Furthermore, the data were used to estimate the lifetime cancer risk for THMs from drinking water, using age-adjusted factors and volatilization terms.

\section{MATERIALS AND METHODS}

Data on THM levels in drinking water throughout Taiwan were obtained from the annual reports of the Environmental Protection Administration (EPA) of Taiwan. Both raw water and chlorinated drinking water samples were collected from three regional water treatment plants in Taiwan from 1994 to 1997. The raw water and treated water were collected once every month from the three water treatment plants. The raw water at these waterworks was pretreated and disinfected with chlorine $(10 \sim 20 \mathrm{mg} / \mathrm{L})$. Water samples were analyzed for THMs by purge and trap followed by GC/MS or GC/electron capture detection (ECD) (Chang et al., 1996). THMs considered in this study are chloroform (USEPA Group $\mathrm{B}_{2}$ ), bromodichloromethane (USEPA Group $\mathrm{B}_{2}$ ), chlorodibromomethane (USEPA Group $\mathrm{B}_{2}$ ), and bromoform (USEPA Group C) (US EPA, 1999).

Smith (1996) has summarized the USEPA methods for cancer risk assessment, which calculates a slope factor (upper-bound lifetime cancer risk per $\mathrm{mg} \cdot \mathrm{kg}^{-1} \cdot$ day $^{-1}$ ) for many substances. That work combines some "toxicological constants" with predetermined risk levels (a $10^{-6}$ cancer risk) and protective human exposure assumption (e.g., $70 \mathrm{~kg}$ body mass, 30 year exposure, $2 \mathrm{~L}$ /day drinking water ingestion, etc.) to produce risk-based concentrations for contaminants in air, drinking water, edible fish, and soil. We used this information to calculate lifetime cancer risks for THMs and compared the measured environmental levels with EPA's acceptable concentrations. These risks serve as a surrogate for potential health impacts and can be used to prioritize problems for attention in Taiwan. The lifetime average daily doses and incremental cancer risk estimates corresponding to 30-year residential exposures were calculated using the measurements in this study and published exposure guidelines.

The methodology for estimation of target cancer risks (TR) used was provided in USEPA, region III risk-based concentration table (USEPA, 1999). For carcinogenic effects (THMs), risk is expressed as excess probability of contacting cancer over a lifetime (70 years). Because contact rates with tap water for children and adults are different, carcinogenic risks during the first 30 years of life were calculated using age-adjusted factors. The models for estimating target cancer risks (lifetime cancer risks) are

$$
T R=\frac{C C \cdot E F r \cdot[(K \cdot I F A a d j \cdot C P S i)+(I F W a d j \cdot C P S o)]}{A T c \cdot 1000 \frac{\mu \mathrm{g}}{\mathrm{mg}}}
$$


and

$$
\begin{aligned}
I F W a d j \frac{\mathrm{L} \cdot \text { year }}{\mathrm{Kg} \cdot \text { day }}= & \frac{E D c \cdot I R W c}{B W c} \\
& +\frac{(E D t o t-E D c) \cdot I R W a}{B W a},
\end{aligned}
$$

where $C C$ is contaminants in water $(\mu \mathrm{g} / \mathrm{L}), T R$ is target cancer risk, $C P S o$ is carcinogenic potency slope oral (risk per $\mathrm{mg} / \mathrm{kg} / \mathrm{day}$ ), CPSi is carcinogenic potency slope inhaled (risk per $\mathrm{mg} / \mathrm{kg} /$ day), $B W a$ is body weight, adult (70 kg), $B W c$ is body weight, age $1-6$ years $(15 \mathrm{~kg}), A T c$ is averaging time carcinogens (25,550 days), IFAadj is inhalation factor, age-adjusted (11.66 $\mathrm{m}^{3}$-years/kg-days), IRWa is tap water ingestion, adult ( $2 \mathrm{~L} /$ day), $I R W c$ is tap water ingestion, age $1-6$ years (1 L/day), IFWadj is tap water ingestion factor, age-adjusted (1.09 L-years $/ \mathrm{kg}$ days), $E F r$ is exposure frequency (350 days/year), $E D t o t$ is exposure duration, total (30 years), $E D c$ is exposure duration, age 1-6 years (6 years), and $K$ is volatilization factor $\left(0.5 \mathrm{~L} / \mathrm{m}^{3}\right)$.

\section{RESULTS AND DISCUSSION}

\section{Concentrations of THMs in Raw and Chlorinated Water}

Table 1 shows the geometric mean THMs concentration $(\mu \mathrm{g} / \mathrm{L})$ in raw and chlorinated water collected from three different water supply plants and one well water source in Taiwan (1994 1997). THM concentrations (geometric means) in chlorinated water have the following ranges: chloroform $\left(\mathrm{CHCl}_{3}\right)$, $4.2 \sim 27.6 \mu \mathrm{g} / \mathrm{L}$; bromodichloromethane $\left(\mathrm{CHCl}_{2} \mathrm{Br}\right)$, $3.24 \sim 6.35 \mu \mathrm{g} / \mathrm{L}$; chlorodibromomethane $\left(\mathrm{CHClBr}_{2}\right)$, $0.63 \sim 4.19 \mu \mathrm{g} / \mathrm{L} ; \quad$ and bromoform $\left(\mathrm{CHBr}_{3}\right)$,
$0.08 \sim 0.68 \mu \mathrm{g} / \mathrm{L}$. Chloroform was the major species of THMs, especially in the water plant of south Taiwan. Similar results were also observed in Korea (Shin et al., 1999). The bromo-THMs, including $\mathrm{CHBr}_{3}, \mathrm{CHBr}_{2} \mathrm{Cl}$, and $\mathrm{CHBrCl}_{2}$, were present in lower concentrations than $\mathrm{CHCl}_{3}$. In most studies, concentrations of $\mathrm{CHBr}_{3}$ are nondetectable, whereas those of $\mathrm{CHBr}_{2} \mathrm{Cl}$ are very low and do not vary with time (Chang et al., 1996). In addition, the lowest THM $(18.4 \mu \mathrm{g} / \mathrm{L})$ concentration was observed in central Taiwan, which also had the lowest TOC concentration. Chang et al. (1996) reported that chemical oxygen demand (COD) had a strong positive correlation with chlorine demand, which suggests that COD could be regarded as a surrogate parameter for water quality concerns.

THMs in drinking water are regulated at a maximum contaminant level (MCL) of $100 \mu \mathrm{g} / \mathrm{L}$ for the sum of the four THMs in Taiwan. However, it is probable that MCL will soon be lowered to $10 \sim 25 \mu \mathrm{g} / \mathrm{L}$, because total trihalomethane levels $>100 \mathrm{ppb}$ reduced birth weight among term births (Bove et al., 1995). From the risk-based concentration (RBC) table of the USEPA it is found that the total risk-based concentration (TRBC) for THMs is $2.85 \mu \mathrm{g} / \mathrm{L}$ (sum of RBC for $\mathrm{CHCl}_{3}, \mathrm{CHBrCl}_{2}$, $\mathrm{CHBr}_{2} \mathrm{Cl}$, and $\mathrm{CHBr}_{3}$ ) (USEPA, 1999; Smith, 1996). Figure 1 shows the GM concentration of THMs in raw water from various water sources generally less than TRBC $(2.85 \mu \mathrm{g} / \mathrm{L})$ of the USEPA. The concentrations of THMs in chlorinated water are much higher than those in raw water by about $9.44,6.67$, and 23.1 times for north, central, and south Taiwan, respectively. As shown in Fig. 2, chloroform concentrations of both surface and ground water are much higher than the RBC for chloroform of the USEPA by

TABLE 1

Geometric Mean Trihalomethanes (THMs) Concentration $(\mu \mathrm{g} / \mathrm{L})$ in Raw and Chlorinated Water Collected from Different

\begin{tabular}{|c|c|c|c|c|c|c|c|c|}
\hline \multirow[b]{2}{*}{ Chemical } & \multicolumn{2}{|c|}{ North Taiwan } & \multicolumn{2}{|c|}{ Central Taiwan } & \multicolumn{2}{|c|}{ South Taiwan } & \multicolumn{2}{|c|}{ South Taiwan* } \\
\hline & $\begin{array}{l}\text { Raw } \\
\text { water }\end{array}$ & $\begin{array}{l}\text { Chlorinated } \\
\text { water }\end{array}$ & $\begin{array}{l}\text { Raw } \\
\text { water }\end{array}$ & $\begin{array}{l}\text { Chlorinated } \\
\text { water }\end{array}$ & $\begin{array}{l}\text { Raw } \\
\text { water }\end{array}$ & $\begin{array}{l}\text { Chlorinated } \\
\text { water }\end{array}$ & $\begin{array}{l}\text { Raw } \\
\text { water }\end{array}$ & Chlorinated \\
\hline Chloroform $\left(\mathrm{CHCl}_{3}\right)$ & 2.05 & 14.2 & 2.30 & 14.4 & 1.50 & 27.6 & 1.68 & 4.19 \\
\hline $\begin{array}{l}\text { Bromodichloromethane } \\
\quad\left(\mathrm{CHCl}_{2} \mathrm{Br}\right)\end{array}$ & 0.32 & 5.12 & 0.27 & 3.24 & 0.06 & 6.35 & ND & 0.11 \\
\hline
\end{tabular}
Water Supply Plants and Water Sources of Taiwan (1994 1997)

Note. ND, bromodibromomethane $<0.03$, chlorodibromomethane $<0.03$, bromofrom $<0.02 \mu \mathrm{g} / \mathrm{L}$, respectively.

*Well water. 


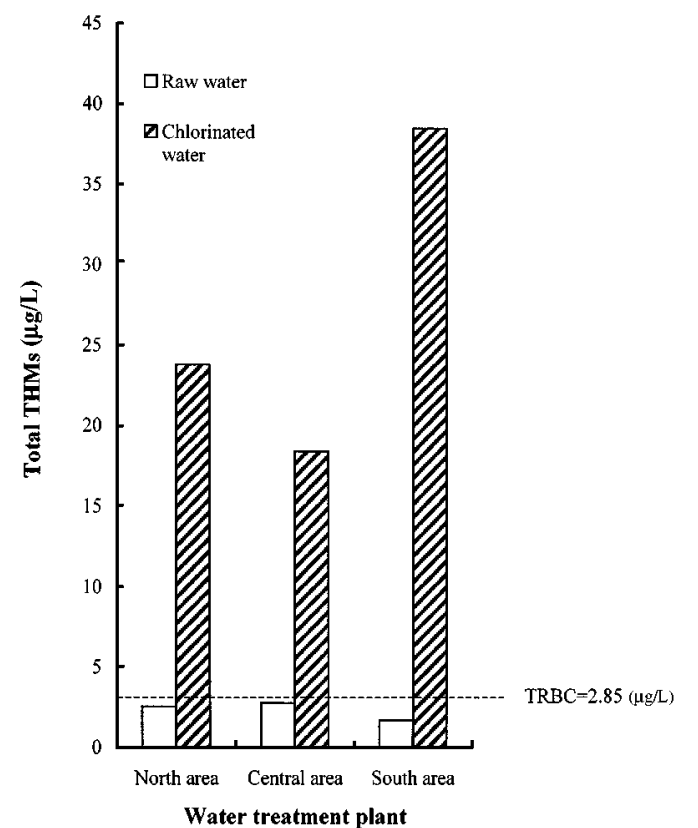

FIG. 1. Total THMs in raw and chlorinated water of different areas of Taiwan compared to the total risk-based concentration (TRBC) of USEPA.

about 184 and 27.9 times, respectively. Higher chloroform concentrations are observed in surface water than in groundwater. Higher chloroform concentrations in surface water could be attributed to

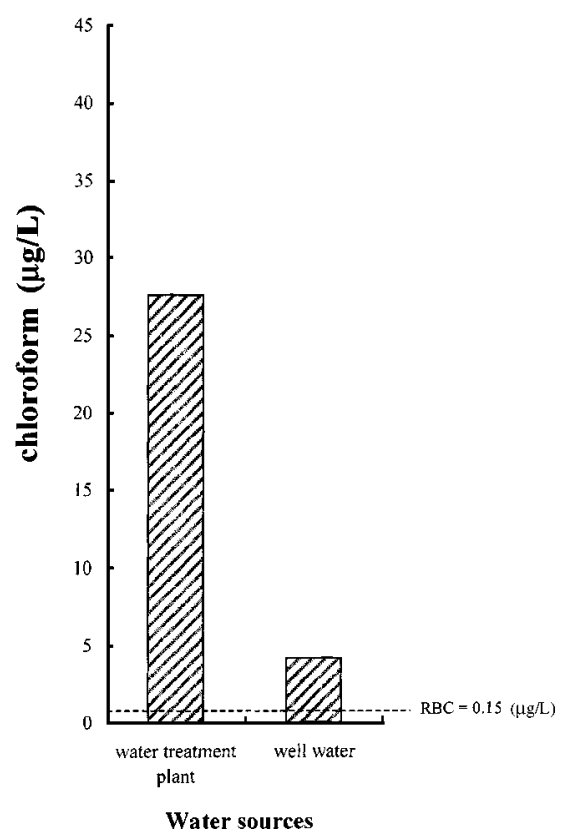

FIG. 2. Chloroform concentrations in drinking water after being chlorinated from different water sources of south Taiwan compared to the risk-based concentration (RBC) for chloroform of USEPA.

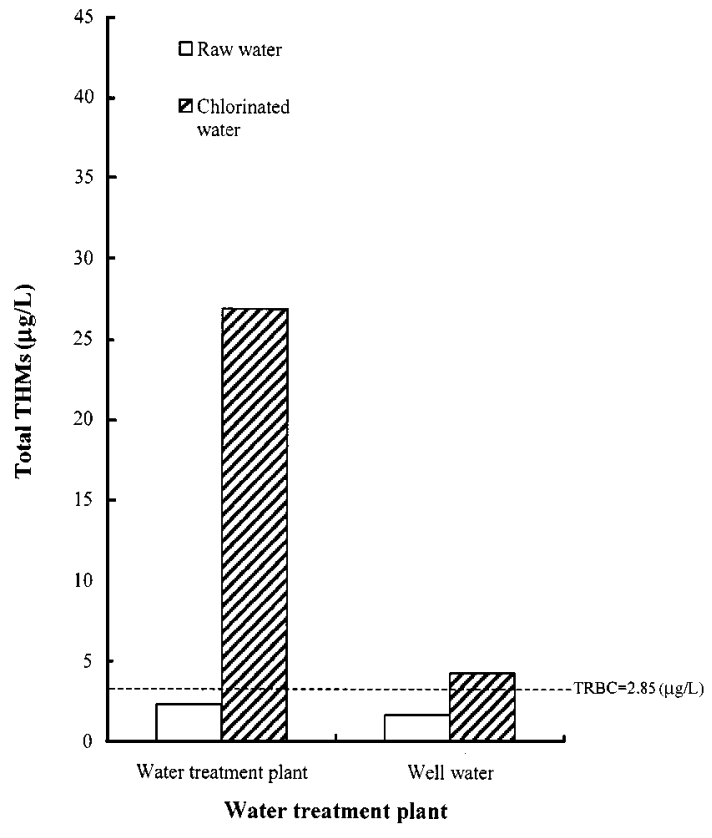

FIG. 3. Total THMs in raw and chlorinated water of Taiwan compared to the total risk-based concentration (TRBC) of USEPA.

total dissolved organic matter concentrations. Chang et al. (1996) found the highest concentration of TOC $(23 \mathrm{mg} / \mathrm{L})$ in raw water collected from water supplies of south Taiwan. After chlorination, the concentration of THMs in chlorinated surface water is much higher than that of RBC of the USEPA. THMs in chlorinated ground water are slightly higher than that of TRBC for THMs of the USEPA (Fig. 3). A similar analysis of volatile organic compound concentrations in Taiwan's drinking water has been reported (Kuo et al., 1997).

\section{Estimation of Lifetime Cancer Risks for THMs}

Potential human health risks associated with THM uptake for tap water and well water were evaluated. Carcinogenic risks were estimated by multiplying the exposure estimate by the carcinogenic slope factor for consuming four THM compounds, $6.10 \times 10^{-3}, 6.20 \times 10^{-2}, 8.40 \times 10^{-2}$, and $7.90 \times 10^{-3}(\mathrm{mg} / \mathrm{kg} / \text { day })^{-1}$ for $\mathrm{CHCl}_{3}, \mathrm{CHBrCl}_{2}$, $\mathrm{CHBr}_{2} \mathrm{Cl}$, and $\mathrm{CHBr}_{3}$, respectively (USEPA, 1999).

Table 2 shows the various estimated lifetime cancer risks for four THM compounds associated with different chlorinated water at various consumption rates. These risks varied with different water sources, water supply areas, and consumption rates. For example, based on a consumption rate of $1 \sim 3$ liter/day, all lifetime cancer risks for $\mathrm{CHCl}_{3}$, 
TABLE 2

Estimated Lifetime Cancer Risks for THMs from Ingested Different Water at Various Ingestion Rates (1-3 liter)

\begin{tabular}{|c|c|c|c|c|c|c|c|c|c|c|c|c|}
\hline \multirow{2}{*}{ Chemical $\left(\times 10^{-6}\right)$} & \multicolumn{9}{|c|}{ Tap water } & \multirow{2}{*}{\multicolumn{3}{|c|}{$\begin{array}{l}\text { *Well water } \\
\text { South area }\end{array}$}} \\
\hline & \multicolumn{3}{|c|}{ North area } & \multicolumn{3}{|c|}{ Central area } & \multicolumn{3}{|c|}{ South area } & & & \\
\hline Chloroform $\left(\mathrm{CHCl}_{3}\right)$ & 91.6 & 92.3 & 92.5 & 93.1 & 93.2 & 93.9 & 178 & 179 & 180 & 27.0 & 27.2 & 27.3 \\
\hline $\begin{array}{l}\text { Bromodichloromethane } \\
\quad\left(\mathrm{CHCl}_{2} \mathrm{Br}\right)\end{array}$ & 3.22 & 4.74 & 6.22 & 2.03 & 2.99 & 3.93 & 3.99 & 5.87 & 7.70 & 0.069 & 0.101 & 0.133 \\
\hline
\end{tabular}

${ }^{a}$ Not determined.

$\mathrm{CHBrCl}_{2}, \mathrm{CHBr}_{2} \mathrm{Cl}$, and $\mathrm{CHBr}_{3}$ from consuming tap water of three water supply areas were higher than $10^{-6}$, the lower end of the range of acceptable risk by the USEPA. The highest lifetime cancer risk of $1.80 \times 10^{-4}$ (based on 3 liter water/day) was for chloroform in tap water from water supply plants of south Taiwan, and this was higher than the risks from well water $\left(2.73 \times 10^{-5}\right)$.

A risk additivity hypothesis was assumed for four THMs. Table 2 shows the risk values for the populations in several areas calculated for each substance and the additive risks to take all THMs into consideration. Exposure to multiple toxicants may result in additive and/or interactive effects. Interactive effects may be synergistic or antagonistic. The USEPA sets exposure standards using an additive model (Hallenbeck, 1993). Accordingly, the sum of lifetime cancer risks for $\mathrm{CHCl}_{3}, \mathrm{CHBrCl}_{2}, \mathrm{CHBr}_{2} \mathrm{Cl}$, and $\mathrm{CHBr}_{3}$ was highest (total risk for total THMs = $1.94 \times 10^{-4}$ ) from consuming tap water from south Taiwan. All additive lifetime cancer risks for THMs from consuming tap water and well water were higher than $10^{-5}$ (Table 2). Based on consumption of 2 liter/day, the lifetime cancer risks for THMs of consuming tap water and groundwater from the four different water supply areas were higher than the EPA acceptable risk $\left(10^{-6}\right)$ by about $99.8,97.1,190$, and 27.6 times, respectively (Table 2). Figure 4 shows the percentage contribution of total risks for various THM compounds in tap water collected from three water supply areas in Taiwan. The lifetime cancer risks for chloroform made the highest percentage contribution (range from 87.5 to $92.5 \%$ ) to total risks. Lahey and Connor (1983) calculated that the risk from drinking water is about $3.4 \times 10^{-5}$, with more than half of the risks coming from chloro- form contamination. Our findings are in no way intended to suggest that the disinfection of drinking water with chlorine should be abandoned. However, it should not be forgotten.
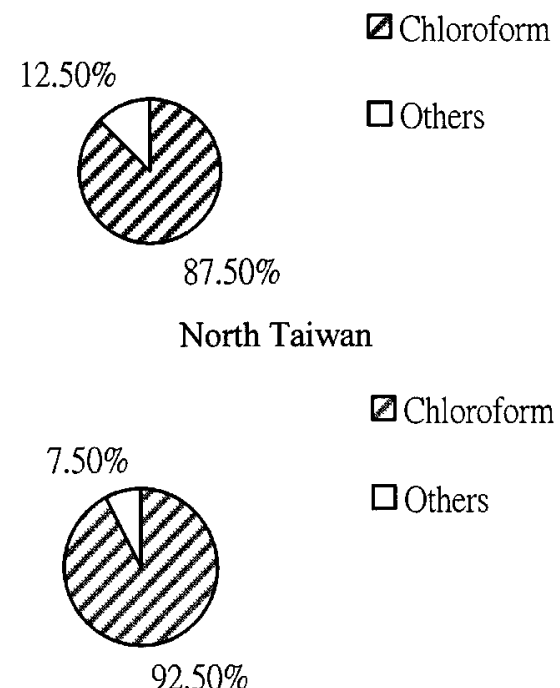

Central Taiwan

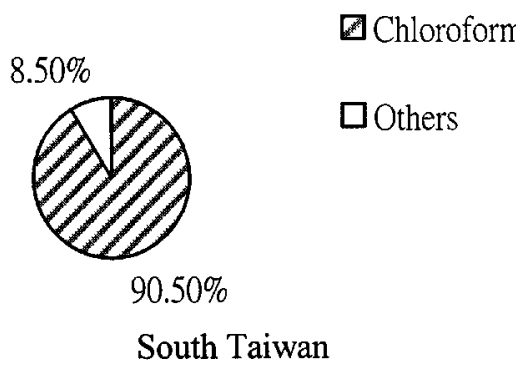

FIG. 4. The percentage contribution of total risks for various THMs from three water treatment plants of Taiwan. 
In the United States many drinking water regulations for organic chemicals are based on the goal of minimizing the risk of developing cancer. The level of acceptable risk in the United States is currently considered to be between one-in-ten-thousand and one-in-a-million. In the underdeveloped world, however, millions of children under the age of 5 years die each year due to waterborne infectious diseases. Thus, the goal of the water supply engineering in this situation is significantly different. When comparing the risk of death from microbiological pathogens in drinking water with the risk of cancer from disinfection by-products, the risk of illness and death from those pathogens is 100 to 1000 times greater than the risk of cancer.

\section{REFERENCES}

Bove, F. J., Fulcomer, M. C., Klotz, J. B., Esmart, J., Dufficy, E. M., and Savrin, J. E. (1995). Public drinking water contamination and birth outcomes. Am. J. Epidemiol. 141, 850-862.

Bull, R. J., Birnbaum, L. S., Cantor, K. P., Rose, J. B., Butterworth, B. E., Pegram, R., and Tuomisto, J. (1995). Water chlorination: Essential process or cancer hazard. Fund. Appl. Toxicol. 28, 155-166.

Cantor, K. P., Lynch, C. F., Hildesheim, M. E., Dosemeci, M., Lubin, J., Alavanja, M., and Craun, G. (1999). Drinking water source and chlorination byproducts in Iowa. III. Risk of brain cancer. Am. J. Epidemiol. 150, 552-560.

Cantor, K. P., Lynch, C. F., Hildesheim, M. E., Dosemeci, M., Lubin, J., Alavanja, M., and Craun, G. (1998). Drinking water source and chlorination byproducts. I. Risk of bladder cancer. Epidemiology 9, 21-28.

Chang, E. E., Chao, S. H., Chiang, P. C., and Lee, J. F. (1996). Effects of chlorination on THMs formation in raw water. Toxicol. Environ. Chem. 56, 211-225.

Doyle, T. J., Zheng, W., Cerhan, J. R., Hong, C. P., Sellers, T. A., Kushi, L. H., and Folsom, A. R. (1997). The association of drinking water source and chlorination by-products with cancer incidence among postmenopausal women in Iowa: A prospective cohort study. Am. J. Public Health 87, 1168-1176.

Dunnick, J. K., and Melnick, R. L. (1993). Assessment of the carcinogenic potential of chlorinated water: experimental studies of chlorine, chloramine, and trihalomethanes. J. Natl. Cancer Inst. 85, 817-822.

Environmental Protection Administration (EPA). (1996). "Year Book of Environmental Statistics, Taiwan Area, Republic of China," pp. 79-113. Office of Statistics, Taipei, Taiwan.

Flaten, T. P. (1992). Chlorination of drinking water and cancer incidence in Norway. Int. J. Epidemiol. 21, 6-15.

Hallenbeck, W. H. (1993). "Quantitative Risk Assessment for Environmental and Occupational Health." Lewis, Chelsea, MI.
Hildesheim, M. E., Cantor, K. P., Lynch, C. F., Dosemeci, M., Lubin, J., Alavanja, M., and Craun, G. (1998). Drinking water source and chlorination byproducts. II. Risk of colon and rectal cancers. Epidemiology 9, 29-35.

Jo, W. K., Weisel, C. P., and Lioy, P. J. (1990). Routes of chloroform exposure and body burden from showering with chlorinated tap water. Risk Anal. 10, 575-580.

Kuo, H. W., Chiang, T. F., Lo, I. I., Lai, J. S., Chan, C. C., and Wang, J. D. (1997). VOC concentration in Taiwan's household drinking water. Sci. Total Environ. 208, 41-47.

Kramer, M. D., Lynch, C. F., Isacson, P., and Hanson, J. W. (1992). The association of waterborne chloroform with intrauterine growth retardation. Epidemiology 3, 407-413.

Lahey, W., and Connor, M. (1983). The case for ocean waste disposal. Technol. Rev. (August-September), 60-70.

Lawrence, C., Taylor, P., Trock, B., and Reilly, A. (1984). Trihalomethanes in drinking water and human colorectal cancer. J. Natl. Cancer Inst. 72, 563-568.

Maxwell, N. I., Burmaster, D. E., and Ozonoff, D. (1991). Trihalomethanes and maximum contaminant levels: The significance of inhalation and dermal exposures to chloroform in household water. Regul. Toxicol. Pharmacol. 14, 297-312.

McGeehin, M. A., Reif, J. S., Becher, J, C., and Mangione, E. J. (1993). Case-control study of bladder cancer and water disinfection methods in Colorado. Am. J. Epidemiol. 138, 492-501.

Morris, R. D., Audet, A. M., Angelillo, I. F., Chalmers, T. C., and Mosteller, F. (1992). Chlorination by-products and cancer: A meta-analysis. Am. J. Public Health 82, 955-962.

Shin, D., Chung, Y., Choi, Y., Kim, J., Park, Y., and Kum, H. (1999). Assessment of disinfection by-products in drinking water in Korea. J. Exposure Anal. Environ. Epidemiol. 9, 192-199.

Smith, R. L. (1996). Risk-based concentrations: Prioritizing environmental problems using limited data. Toxicology 106, 243-266.

USEPA (1999). Risk-Based Concentration Table, USEPA, Region III 841 Chestnut Street, Philadelphia, PA.

Waller, K., Swan, S. H., DeLorenze, G., and Hopkins, B. (1998). Trihalomethanes in drinking water and spontaneous abortion. Epidemiology 9, 134-140.

Weisel, C. P., Kim, H., Haltmeier, P., and Klotz, J. B. (1999). Exposure estimates to disinfection by-products of chlorinated drinking water. Environ. Health Perspect. 107, 103-110.

Weisel, C. P., and Jo, W. K. (1996). Ingestion, inhalation, and dermal exposures to chloroform and trichloroethane from tap water. Environ. Health Perspect. 104, 48-51.

Wilkins, J., Reiches, N., and Kruse, C. (1979). Organic chemical contaminants in drinking water and cancer. Am. J. Epidemiol. 110, 420-448.

Yang, C. Y., Chiu, H. F., Cheng, M. F., and Tsai, S. S. (1998). Chlorination of drinking water and cancer mortality in Taiwan. Environ. Res. 78, 1-6.

Yang, C. Y., Chiu, J. F., Chiu, H. F., Wang, T. N., Lee, C. H., and Ko, Y. C. (1996). Relationship between water hardness and coronary mortality in Taiwan. J. Toxicol. Environ. Health 49, 1-9. 